\title{
КРИТЕРІЇ ТА ПОКАЗНИКИ ПСИХОЛОГІЧНОЇ ГОТОВНОСТІ МАЙБУТНІХ ФАХІВЦІВ АГРАРНОЇ ГАЛУЗІ ДО ПРОФЕСІЙНОЇ ДІЯЛЬНОСТІ
}

У статті подано критерії психологічної готовності майбутніх фахівців аграрної галузі до професійної діяльності (мотиваційна готовність, иіннісна готовність, рефлексивна готовність, когнітивна готовність, діяльнісна готовність, регулятивна готовність) та їх показни$\kappa u$.

Ключові слова: психологічна готовність до професійної діяльності, критерії, показники.

В статье представлень критерии психологической готовности будуших специалистов аграрной отрасли к профессиональной деятельности (мотивационная готовность, иченностная готовность, рефлексивная готовность, когнитивная готовность, деятельностная готовность, регулятивная готовность) и их показатели.

Ключевые слова: психологическая готовность к профессиональной деятельности, критерии, показатели.

There are presented the criteria of psychological readiness of future specialists in agriculture to the profession activity (motivational readiness, valuable commitment, reflexive readiness, cognitive readiness, activity readiness, regulatory readiness) and their indicators in the article. cators.

Key words: Psychological readiness to the profession activity, criteria, indi-

Розвиток сучасного суспільства характеризується високим ступенем динамізму, невизначеності, що відбивається на всіх рівнях життя сучасної людини - глобальному, регіональному, соціальному, індивідуальному.

Наукові дослідження свідчать, що фінансова успішність лише на $15 \%$ зумовлена професійними знаннями, на $85 \%$ вміннями взаємодіяти 3 колегами, схиляти людей до власної позиції, презентувати свої ідеї, з особистісними якостями і здібностями [1]. Отже, ефективність і якість професійної діяльності зумовлюється особливостями психологічної готовності фахівців до здійснення професійної діяльності.

Аналіз останніх досліджень і публікацій свідчить, що психологічна підготовка фахівців досліджується як педагогами, так і психологами. Переважна більшість досліджень 
стосується психологічної підготовки педагогічних кадрів (В. Вовк, Н. Денисова, Д. Дзвінчук, О. Кажарська, В. Козаков, С. Лисенко, Н. Молодиченко, І. Овдієнко В. Семиченко, С. Ткаченко, В. Федорчук); працівників прикордонної служби (С. Мул, О. Самохвалов); персоналу морського транспорту (С. Ситнік); міліції (О. Корнєв, I. Машук, М. Рогачов); льотчиків (І. Окуленко); юристів (Ю. Бойко); спортсменів (С. Кузьміна, О. Федик, О. Черепехіна).

Мотивам і мотивації присвячено велику кількість монографій (В. Асєєв, Дж. Аткінсон, М. Магомед-Емінов, К. Мадлен, А. Маслоу, В. Мерлін, П. Симонов, Д. Узнадзе, А. Файзуллаєв, Г. Холл, П. Якобсон, Х. Хекхаузен та ін.). Проблему цінностей у вітчизняній психолого-педагогічній науці вивчали Б. Ананьєв, Г. Андреєва, І. Бех, Є. Бондаревська, М. Боришевський, I. Зимня, I. Зязюн, 3. Карпенко, С. Рубінштейн, В. Сластьонін, О. Хуторський, В. Ядов, Т. Яценко та ін. Проблема розвитку професійної рефлексії у студентів у контексті особистісно зорієнтованого підходу вивчалася Г. Загвязинським, Ю. Кулюткіним, I. Ладенко, I. Семеновим, Ю. Степановим, Г. Сухобською, Н. Чепелєвою. Проблеми регулятивної сфери особистості досліджували Л. Виготський, О. Конопкін, О. Леонтьєв, В. Моросанова, С. Рубінштейн, В. Селіванов та ін.

Аналіз літератури є теоретичним підгрунтям для обгрунтування критеріїв і показників психологічної готовності майбутнього фахівця аграрної галузі до професійної діяльності.

Mema cmammi - теоретично обгрунтувати критерії та показники психологічної готовності майбутнього фахівця аграрної галузі до професійної діяльності.

До структури психологічної готовності майбутнього фахівця аграрної галузі до професійної діяльності віднесено такі компоненти: мотиваційний, ціннісний, рефлексивний, когнітивний, діяльнісний, регулятивний [2-10].

Визначаючи критерії й показники психологічної готовності майбутнього фахівця аграрної галузі до професійної діяльності, ми спиралися на наукове тлумачення змісту цих категорій: 1) критерій - одна з основних ознак, мірило для визначення, оцінки, класифікації чого-небудь [11, с. 567]; 2) критерій - набір якісних характеристик, що використовуються для винесення судження щодо виконання, продукту виконання або як інструмент оцінювання; найзагальніша 
сутнісна ознака, на основі якої здійснюють оцінку, порівняння реальних педагогічні явищ, при цьому рівень виявлення, якісна сформованість, визначеність критерію виражається в конкретних показниках; ознака, завдяки якій відбувається оцінка, визначення або класифікація явища або процесу [12]; 3) показник - свідчення, доказ, ознака чого-небудь; наочні дані про результати якоїсь роботи, якогось процесу; дані про досягнення в чому-небудь; дані, які свідчать про кількість чого-небудь [13, с. 520].

Отже, в межах нашого дослідження критерій - це об'єктивна сутнісна ознака психологічної готовності майбутнього фахівця аграрної галузі до професійної діяльності, за допомогою якої здійснюється оцінка ії сформованості; показник - результат психологічної підготовки студентіваграрників, що відображає якісну сформованість і характеристику професійно значущих психологічних знань, умінь, навичок, особистісних якостей майбутнього фахівця агарної галузі. Нами враховувано вимоги до визначення критеріїв: a) об'єктивність і цілісність у функціональній системі; б) ефективність, тобто досить повне відображення чинників, що впливають на оцінюваний параметр педагогічного процесу; в) адекватність (критерій має адекватно відображати властивості, явища); г) надійність і висока вірогідність (достатність статистичних оцінок критерію); д) спрямованість, що означає: критерій має бути спрямованим на управління діяльністю; е) критерій має відображати відносну значущість властивостей об'єкта, що оцінюється [14, с. 106].

У процесі визначення показників ми керувалися тим, що вони повинні відображати реальні результати й характер діяльності та їх можна було б легко і швидко зареєструвати $[15$, с. 15$]$.

Зважаючи на зазначене вище та у відповідності з компонентами психологічної готовності майбутнього фахівця аграрної галузі до професійної діяльності визначено такі критерії: мотиваційна готовність, ціннісна готовність, рефлексивна готовність, когнітивна готовність, діяльнісна готовність, регулятивна готовність. Розглянемо більш детально показники окреслених критеріїв.

1. Показниками мотиваційної готовності $є$ рівень вмотивованості студентів до:

- власної відповідальності за своє майбутнє; 
- позитивного, емоційно-ціннісного ставлення та стійкий інтерес до професії аграрника;

- освоєння професії на високому рівні;

- усвідомлення кінцевих цілей навчання;

- досягнення поставлених цілей;

- самоактуалізації, самопізнання й особистісного розвитку;

- професійній самореалізації;

- визнання, поваги з боку оточуючих;

- самовираження;

- досягнення успіху в професіі;

- високого рівня домагань;

- $\quad$ контактів із людьми на підгрунті довіри і співробітництва;

- альтруїстичного ставлення до інших.

Для оцінювання показників мотиваційної готовності доцільно використовувати такі методики: «Мотивация аффилиации» (методика А. Мегрябана в модифікації М. МагомедЕмінова), «Мотивация успеха и боязнь неудачи» (методика А. Реана), «Потребность в достижении» (методика Ю. Орлова), «Диагностика уровня эмпатии» (методика В. Бойко), «Диагностика социально-психологических установок личности в мотивационно-потребностной сфере» (методика О. Потьомкіної), «МАС» (методика М. Кубишкіної), «Мотивация обучения в вузе» (методика Т. Ільїної), «Методика оценки уровня притязаний личности» (опитувальник В. Гербачевського).

2. Показниками ціннісної готовності $є$ рівень сформованості цінностей студентів:

- професійних - суспільної значущості праці аграрника; власної відповідальності за майбутнє і збереження існування людства; збереження довкілля і раціонального використання природних ресурсів України; професійного зростання й досягнення успіху в професійній діяльності; професійної самореалізації; професіоналізму; відданості професії; позитивного ставлення до оточення; цінностей, що відображають альтруїстичний характер професійної діяльності (допомога іншим, піклування про них); аффілятивних цінностей;

- особистісних - сенсожиттєвого вибору і змістового наповнення діяльності; розкриття й реалізації власного по- 
тенціалу, самоствердження; самопізнання, само-актуалізації, самовдосконалення; власної індивідуальності; цінність освіченості та самоосвіти протягом життя; морально-етичних принципів.

Для оцінювання показників ціннісної готовності доцільно використовувати «Методику изучения смысложизненных ориентаций» (методика Д. Леонтьєва); «Морфологічний тест життєвих цінностей» (методика В. Сопова, Л. Капушиної).

3. Показниками рефлексивної готовності є рівень сформованості здатностей студентів:

- на особистісному рівні - розуміти і пізнавати себе; аналізувати власні думки; усвідомлювати і розуміти те, як суб'єкт мислить, що він знає; усвідомлювати власні переживання; емоційно ставитися до того, що суб'єкт усвідомлює; відстежувати власні психічні стани; перебувати в зовнішній позиції; осмислювати й переосмислювати стереотипи власної поведінки; прогнозувати наслідки власних дій, планувати діяльність й управляти нею; осмислювати і творчо долати проблемні ситуації; визначати цілі і завдання діяльності, усвідомлювати причини власних успіхів і невдач; здатності до самосхвалення і самокритики;

- на міжособистісному рівні - до розуміння психіки та обміркування поведінки інших людей; розуміння інших i здатність поставити себе на їх місце; «бачити» й оцінювати життєві та професійні ситуації; прогнозування дій і вчинків навколишніх; до виявлення причин труднощів у взаємодії 3 оточенням.

Для оцінювання показників рефлексивної готовності доцільно використовувати «Методику определения уровня развития рефлексивности» (методика А. Карпова), «Методика определения уровня выраженности и направленности рефлексии» (методика М. Гранта).

4. Показниками когнітивної готовності є рівень сформованості знань студентів про:

- психологічні вимоги до особистості фахівцяаграрника;

- основні закони, принципи, закономірності наукової психології;

- сучасні науково-теоретичні підходи до вивчення людини як суб'єкта діяльності та пізнання; 
- якісні, структурні, класифікаційні характеристики психічних властивостей, станів і процесів особистості;

- мотиваційну, пізнавальну, емоційно-вольову сферу особистості, їх розвиток та регуляцію;

- індивідуально-психологічні особливості особистості та їх розвиток;

- психологічну структуру діяльності;

- психологічні особливості й закономірності спілкування особистості;

- діагностичні методи і методики вивчення психічних процесів, властивостей і станів особистості.

Оцінювання показників когнітивної готовності здійснюється під час роботи студентів на семінарських заняттях, за результатами виконання індивідуальних завдань, за результатами поточного та підсумкового контролю знань.

5. Показниками діяльнісної готовності є рівень сформованості вмінь і навичок студентів:

- використовувати наукові психологічні знання в життєвих і професійних ситуаціях, у процесі реальної взаємодії 3 іншими та в інтересах самопізнання й саморозвитку;

- розпізнавати й ідентифікувати психічні явища, які зумовлюють поведінку особистості, іiі діяльності та спілкування;

- правильно орієнтуватися в поведінці людей, розуміти мотиви вчинків і регулювати взаємовідносини;

- здійснювати цілепокладання; діяльність;

- планувати, моделювати, програмувати власне життя i

- самооцінювати результати власної діяльності;

- коригувати самооцінку;

- здійснювати рефлексію;

- здійснювати особистісну саморегуляцію, саморегуляцію поведінки і діяльності;

- володіти техніками і прийомами ефективного спілкування;

- ідентифікувати й інтерпретувати невербальну інформацію процесу спілкування;

- адекватно розв' язувати конфліктні ситуації;

- розвивати власні відчуття, пам'ять, мислення, уяву, увагу, здібності; 
- визначати психічні стани та використовувати особистісні резерви;

- керувати власними переживаннями;

- долати наслідки нервово-психічних перенапружень і фрустрацій;

- володіти діагностичними методами й методиками вивчення психічних процесів, властивостей і станів;

- самостійно працювати 3 науковою психологічною літературою.

Оцінювання показників діяльнісної готовності здійснюється під час роботи студентів на семінарських заняттях та за результатами виконання індивідуальних завдань.

6. Показниками регулятивної готовності є такі:

- регуляція цілей діяльності;

- довільне регулювання суб'єктом дій, пов'язаних із організацією і здійсненням діяльності;

- регуляція зовнішніх і внутрішньо значущих для досягнення цілей умов;

- у уміння продумувати способи власних дій і поведінки досягнення цілей;

- оцінювання суб'єктом себе і результатів своєї діяльності та поведінки;

- регуляція мотиваційно-ціннісної, пізнавальної й афективної сфер;

- регуляція ставлень до себе, до інших та професійної діяльності.

Для оцінювання показників регулятивної готовності доцільно використовувати такі методики: «Шкала совестливости» (методика В. Мельникова, Л. Ямпольського); «Стиль саморегуляции поведения - ССП-98» (методика В. Моросанової).

Визначені критерії психологічної готовності майбутніх фахівців аграрної галузі до професійної діяльності (мотиваційна готовність, ціннісна готовність, рефлексивна готовність, когнітивна готовність, діяльнісна готовність, регулятивна готовність) та їх показники взаємопов'язані, взаємозумовлюються і лише в єдності забезпечують ефективність професійної діяльності аграрників.

Актуальними напрямами подальшої роботи є визначення рівнів сформованості психологічної готовності фахівців аграрної галузі до професійної діяльності. 


\section{Література}

1. Рубанова Е. Ю. Психологическая готовность выпускников вуза к профессиональной деятельности / Е. Ю. Рубанова // Ученые заметки ТОГУ, 2011. - Т. 2. - №1. - С. 53-62. 2. Ильин Е. П. Мотивы и мотивация / Евгений Павлович Ильин. - СПб. : Питер, 2008. - 512 с. 3. Радчук Г. Аксіопсихологія вищої школи : [монографія]/ Галина Радчук. - Тернопіль : ТНПУ, 2009. - 425 с. 4. Карпов А. В. Рефлексивность как психическое свойство и методика ее диагностики / А. В. Карпов // Психологический журнал. 2003. - Т. 24. - № 5. - С. 45-57. 5. Петров И. П. Рефлексивный механизм психологической готовности личности к самоопределению (на примере старшеклассников) : автореф. дис. на соискание ученой степени канд. психол. наук / Иван Петрович Петров ; Бурятский университет. - Улан-Удэ, 2004. - 23 с. 6. Семенов И. Н. Проблема предмета и метода психологического изучения рефлексии / И. Н. Семенов, С. Ю. Степанов // Исследование проблемы психологии творчества. - М. : ПЕРСЭ, 1993. - 256 с. 7. Трунов Д. Г. Виды рефлексии: феноменологическое обоснование / Д. Г. Трунов // Вестник Пермского ун-та. : Серия «Психология». - 2009. - Вып. 2(28). - С. 47-58. 8. Конопкин О. А. Психическая саморегуляция произвольной активности человека (структурно-функциональный аспект) / О. А. Конопкин // Вопросы психологии. - 1995. - № 1. С. 5-12. 9. Моросанова В. И. Индивидуальный стиль саморегуляции в произвольной активности человека / В. И. Моросанова // Психологический журнал, 1995. - Т. 16. - № 4. - С. 26 - 35. 10. Моросанова В. И. Личностные аспекты саморегуляции активности человека / В. И. Моросанова // Психологический журнал. 2002. - Т. 23. - № 6. - С. 5-17. 11. Словник іншомовних слів: 23000 слів та термінологічних словосполучень / [уклад. Л. О. Пустовіт та ін.]. - К. : Довіра, 2000. - 1018 с. 12. Макодзей Л. І. Критерії, показники та рівні сформованості управлінської компетентності майбутніх магістрів лісового господарства [Електронний ресурс] / Л. I. Макодзей. - Режим доступу: http://www.tmpe.gb7. ru/docs/1/Makodzei.pdf 13. Новий тлумачний словник української мови: В 4 т. - К. : Аконіт, 1999. - Т. 3. - 520 с. 14. Курбатова Ю. В. Розвиток професійного становлення майбутнього агронома в навчально-виховному процесі аграрного університету : дис. ... канд. пед. наук : 13.00.04 / Курбатова Юлія Володимирівна. - Дніпропетровськ, 2011. - 280 с. 15. Лузан П. Г. Формування активності студентів у навчанні / П. Г. Лузан, А. І. Дьомін, В. І. Рябець. - К. : Вища школа, 1998. - $192 \mathrm{c}$. 